\title{
The northern Wathawurrung and Andrew Porteous, 1860-1877
}

\author{
Ian D Clark
}

The operation of the Central Board and the Board for the Protection of Aborigines in Victoria has been studied by Marcard, Penney and Clark. ${ }^{1}$ There are numerous studies of particular stations and reserves that existed during the operation of the Board; for example, Lake Condah, Framlingham, Ebenezer and Coranderrk. ${ }^{2}$ A third tier of study relates to particular individuals and, though these studies are not expressly concerned with their responsibilities as 'Honorary Correspondents' to the Board, they nevertheless discuss relationships with Aborigines. ${ }^{3}$ This paper adds to these studies by concentrating on one of those correspondents, Andrew Porteous.

The Honorary Correspondent Scheme operated in Victoria from 1860 to 1868 under the Central Board to Watch over the Interests of Aborigines, and from 1869 to 1904, under its successor, the Central Board for the Protection of Aborigines. 'Honorary Correspondent' was the term preferred by the Board, until its replacement in 1871 by 'Local Guardian'. Honorary correspondents were appointed by the Board in districts where Aboriginal people lived, particularly in regions that were not served by a government mission station or reserve, or a church-run mission station. Their primary role was to requisition and distribute basic supplies to the Aboriginal peoples living in their neighbourhoods. Another important role of the correspondent to the Board was providing information on the lifestyles of the Aboriginal peoples, and births and deaths. Initially, the Board sent a series of circulars of questions to each correspondent, and their replies were often selectively published in Board reports. Information from some circulars, particularly if it concerned spatial organisation and language, was published by R Brough Smyth, the Secretary to the Board, in his 1878 two-volume publication on Victorian Aborigines. In the introduction to this work, Smyth alludes to the fact that when he commenced as secretary to the Board in 1860, 'it seemed to me to be my duty to collect information respecting the customs of the people who had formerly owned the soil of Australia ... I did not know then that I was commencing a work which would engage all my leisure for many years, and entail upon me a large amount of labor in

1. Marcard 1963, 1964; Penney 1997; Clark 1999.

2. For Lake Condah, see: Massola 1963, 1970; Cole 1984. For Framlingham, see: Barwick 1979, 1981. For Ebenezer, see: Werner 1964; Robertson 1992. For Coranderrk, see: Shaw 1949, MacDonald 1964; Massola 1975; Barwick 1972, 1998.

3. Gannan 1970; Blake nd. 
correspondence alone'. ${ }^{4}$ Penney has noted that the procedures for the appointment of Honorary Correspondents do not appear to have been encoded by the Board. ${ }^{5}$ Her observations are that correspondents were clearly important members of their community - prominent pastoralists, magistrates, medical practitioners or police officers. Many of these men, or at least their stations, were in regular contact with local Aboriginal people.

Many of the honorary correspondents had been in continuous occupation of their stations from the early 1840s and had forged positive relationships with local Aboriginal clans. Some correspondents - such as Colin Campbell at Buangor, Charles Gray at Nareeb Nareeb, and Henry Godfrey at Boort - had been identified by local clans as reincarnated former clanspeople or ngamadjidj. My analysis of this identification is that it had a significant impact on the association between Campbell and Gray and the local clans. ${ }^{6}$ Their cordial interaction remained for many years, with local clan members employed and living on the stations, and sometimes being buried in station cemeteries. Cordial relations with squatters also ensured that Aboriginal people were able to continue to adhere to traditional spatial imperatives, such as the Aboriginal sense of place that ensured that people would want to die in their home countries, and would want to work on squatting stations that were formed on their traditional estates, so that whilst working for Europeans they were also caring for and using the resources of their natal clan. ${ }^{7}$ The Nareeb Nareeb gundidj, the Djabwurrung clan centred on the Nareeb Nareeb pastoral run, although dispossessed in 1840, continued to maintain its relationship with its estate through Barringbittarney, the clan-head, who lived on the station until his death in 1878, when he was buried in the station cemetery. This pattern was replicated across the state, and from 1870, when the Board began to attempt to concentrate the Aboriginal people of Victoria on to select stations and reserves, it permitted the older folk to remain in their traditional lands.

Andrew Porteous was associated with the Clyde Company, and in the early 1840s was the manager of the Carngham station when it was leased by Philip Russell. ${ }^{8}$ In 1853, when Russell Simpson leased Eurambeen from Alexander Campbell, Porteous became manager of the station. In August 1859, in partnership with Philip Russell and James Aitken, Porteous purchased Langi Willi (formerly Bamgamie), 21,364 acres on Mt Emu Creek, near Skipton. ${ }^{9}$ The nature of the partnership is unknown, but it is understood Russell was the major shareholder and Aitken was station manager. ${ }^{10}$ Porteous was appointed an honorary correspondent in 1860 and in correspondence with the Aboriginal Board his location is given variously as Carngham in 1861, Mount Emu in 1866 and Pretty Tower, Stockyard Hill from 1869. It is not known if Porteous lived at the same address during his tenure as Honorary Correspondent and Local Guardian. The Parish map of Carngham reveals that Andrew Porteous purchased land in the

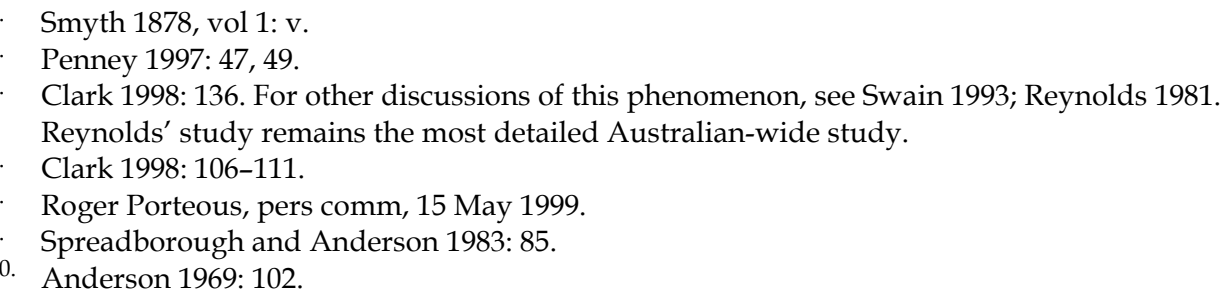


township of Carngham in December 1863 and in partnership with his older brother, James, in August 1855. ${ }^{11}$

Pretty Tower was selected from the western part of the St Enoch's (called Stockyard Hill in the early 1840s) estate in 1866 by Thomas Ralph Oddie and his brother James. According to Anderson, Pretty Tower is a corruption of petit tours, meaning 'a little spring'. ${ }^{12}$ The only habitation then to be seen was on the south bank of Pretty Tower Creek, and was a thick-walled, one-room stone hut with a shingle roof, the home of a St Enoch shepherd and his large family. Thomas Oddie had been pasturing sheep in partnership with Andrew Porteous since 1864, beginning with land belonging to the Oddie brothers (part of which was subject to a mortgage to Charles Kernot). In December 1866, Porteous selected land under the Land Act 1865. He took further land in May 1869. At the end of March 1873, Thomas Oddie and Porteous decided to end their partnership. Andrew Porteous died from 'dropsy' on 1 March 1877, aged 63 and is buried in the Carngham cemetery.

The Carngham district formed part of the country of the Wathawurrung speaking Aboriginal peoples. The clan belonging to Carngham, the Carringum balug, was in 1841 reduced to one adult male, Narnemoon, who had joined with the Gulidjan people at Lake Colac. ${ }^{13}$ Carngham is a corruption of Carringum. During Narnemoon's absence, his clan estate was occupied by clans from neighbouring wurrung (languages): Beeripmo balug (from Mt Cole) and Ngutuwul balug (from Mt Langi Ghiran) (both Djabwurrung), and Galgal balug (from Mt Mitchell and Burnbank, aka Djadjawurrung). ${ }^{14}$ It is no surprise that in the late 1860s when the Mount Cole people were no longer supplied with rations by Colin Campbell at Buangor, that they began to visit the Carngham district's honorary correspondent, Andrew Porteous. In many respects, they were continuing an association that had been active from at least the early 1840s.

James Baillie, the squatter at the Carngham run of 30,000 acres adjoining the township of Carngham, encouraged Aboriginal people to visit his station. Baillie's neighbour, Katherine Kirkland of Trawalla station, disapproved of his relationship with Aboriginal people, and considered him too kind to them, especially when he allowed them to visit his own hut. In 1841, when GA Robinson, Chief Protector of Aborigines in the Port Phillip Aboriginal Protectorate (1839-1849), visited Urquhart's Mount Emu station, the station adjoining Carngham, he met with members of the Beerikwart balug, the local clan. Robinson learned that at this establishment the best possible understanding with the Aboriginal people had existed from its beginning, where they were encouraged and made useful. The station manager, Glendinning, was spoken of in the highest terms, and was called Jacky Jacky by the Aboriginal people. Robinson noted that there were only six Beerikwart people left: two women and four male youths, and they sheltered at Urquhart's Mount Emu and Linton's Emu Hill stations. ${ }^{15}$

Wathawurrung clans adjoining the Carringum balug included the Beerikwart balug belonging to Tarrekurrumbeet (Mt Emu); the Burrumbeet balug at Burrumbeet

\footnotetext{
Victoria Department of Crown Lands and Survey 1938.

Anderson 1969: 106.

Clark 1990: 320.

For a discussion of this probable incident of succession, see Clark 2006.

Robinson's journal entry for 5 August 1841 (Clark 2000).
} 
and Learmonth lakes; the Keyeet balug, a Burrumbeet balug sub-group or patriline associated with Mt Buninyong and Black Hill; and the Wongerrer balug associated with the headwaters of the Wardy Yalloak River. By the 1850s 'traditional' clan labels were rarely used by non-Aboriginal people in western Victoria and the Beerikwart balug had became known as the 'Mount Emu tribe', just as the Beeripmo balug and Ngutuwul balug had become known as the 'Mount Cole tribe'. The Keyeet balug had become known as the 'Buninyong tribe', and the Burrumbeet balug the 'Ballarat tribe'.

Penney has noted that Aboriginal people in Victoria were used to clustering around pastoral stations and towns where supplies were more freely available to them. ${ }^{16}$ They were also using Central Board depots as centres for social gatherings to maintain their social networks. In many cases, the local guardians offered employment to the Aboriginal peoples under their care. Stores were distributed on a weekly or twice-weekly basis. Penney's analysis is that few family groups received supplies from depots. Single people or groups of individuals were better able to take up seasonal work, and to travel to depots to get supplies and to manage on far less rations and clothing. As the non-mission Aboriginal population declined, Penney noted that:

many moved onto missions, others died, and those frequenting depots grew older and became more individualistic. Some married couples remained together, but none travel with children. The few photographs that remain which show such people always depict a camp of aging adults and never are there any children. These people rarely married, as few suitable partners of the 'right' background could now be found. They clustered around a favourite camp site close to a depot for regular supplies and became attached to their Honorary Correspondent who treated them as part of the larger station family in most cases. ${ }^{17}$

Porteous found that he was unable to induce the Aboriginal peoples in his district to remain for any length of time, as they preferred to travel from place to place in small groups. His practice of distributing rations twice weekly may also have contributed to their unwillingness to be stationed in the one place. During very wet winters when it was difficult for them to pursue traditional hunting practices, they camped for longer periods near his home station. This residential pattern of travelling in small groups from place to place is confirmed in the 1863 inquest into the death of Old Donald, of the Mount Emu tribe, who died from hydatids in the liver, at Carngham, 23 October 1863, at which Porteous stated that he had known Old Donald for about 22 years. 'He was a widower, with a son now living at the camps of the Mount Emu tribe in the neighbourhood.' James Miller, a member of the Mount Emu tribe, stated that three months earlier he had been stockriding for Mr Clapperton at Amphitheatre and since then he had been living with his tribe camping in different places in the district. ${ }^{18}$

Francis Ormond, a settler at Borriyallock, replied to the 1859 Victorian Legislative Council's Select Committee on Aborigines. The information he furnished provides us with useful detail of the lives of the Aboriginal peoples of the Ballarat district. Ormond

\footnotetext{
Penney 1997: 71.

Penney 1997: 70.

18. Coroner's Court inquest files, item 1863/928, VPRS 24, Public Record Office of Victoria (PROV). Inquests into Aboriginal deaths are a very valuable source of information, but they are often neglected in historical studies.
} 
estimated the Mount Emu tribe consisted of 17 members with slightly more males than females. Their ages ranged from 20 to 50, and there were two children, a 13-year-old girl, and an 11-year-old male 'half-caste'. He stated that in the years 1853-55, a good many deaths had occurred from venereal disease and accidental deaths by fire whilst in a state of intoxication. Several had died from pulmonary consumption. According to Ormond the Mount Emu tribe lived mostly on the charity of settlers, supplementing their living by catching fish and shooting wild fowl that they sold for money to buy rum. They were employed in sheep-washing, harvesting and cutting wood and were paid in money for these services.

Porteous reported in March 1862 that amongst the people in his district 'habits of intoxication are unfortunately too common, not diminishing, rather increasing ${ }^{\prime}{ }^{19} \mathrm{He}$ gave the Ballarat and Mount Emu Aboriginal population as 63. Porteous reported in 1865 that the:

Mount Emu tribe are pretty comfortable and well contented with provisions and clothing, but can't be induced to remain for any length of time in one place. They prefer roaming about from place to place, depending on charities, and when hard pressed they return for a supply of the Board's stores. The tribe generally roams about in small bands of from 10 to 12 individuals. This may be accounted for the tribe being composed of the remnants of four tribes, viz, Mount Emu, Mount Cole, Ballarat, and Wardyallock tribes. They occasionally meet all together, but it is their custom for each tribe to travel by itself.

The tribe still continue to make possum rugs, and, if steady, might make a good living by it, as they generally get 20s. to 30 s. for each rug, which they can make in 14 days. The women also employ themselves in making baskets and nets, which they sell to the Europeans. A few of the young men are generally employed on stations, and receive a small remuneration, but all they receive, both for labor and opossum rugs, is spent on intoxicating liquors, and I fear that they will not leave off this evil habit unless prohibited from visiting the gold fields and are allowed to settle on some portion of land where they would take an interest in improving it.

A number of the tribe have requested me to apply to the Government to reserve a block of land near Chepstowe for their use, where they might make a paddock, and grow wheat and potatoes, and erect permanent residences. I believe most of the tribe would remain permanently there if land was reserved for their use; their hunting is in the neighbourhood, and there is plenty of water. The young men seem to be very anxious about it; I believe this has arisen from hearing of the comfort and happiness of the Aborigines at Coranderrk.

It would be little or nothing for the Govt. to reserve two sections for a year or two while the tribe lasted. A few more years will see them extinct. In the early part of this year, seven youths were sent from this tribe to Coranderrk. They left Carngham at three o' clock a.m. in a spring cart, to get the first train from Ballarat, and by nine o'clock the same morning, the parents of four of the youths took the road and followed their children, and by slow but continued marches found Coranderrk, and their children comfortable and happy under the care of Mr Green. The parents remained at Coranderrk for upwards of 4 months, and then returned to inform the tribe of the comfort and happiness they had witnessed in the blackfel-

19. Central Board (CBA) 2nd Report 1862. 
lows' township as they called it. On hearing their story, which was very interesting, the king made up his mind to take the whole tribe, and go to see the blackfellows' township; and I have been informed that the Hopkins tribe intend to join them, and proceed to Coranderrk. I think Mr Green might be able to persuade them to leave all the youths of this tribe to be instructed, and should the aged of the tribe prefer to return to their own localities, I think the Board should endeavour to have a block of land reserved for their use, that they might be enabled to imitate the industry they had seen at Coranderrk. ${ }^{20}$

The government did take action to provide a reserve for the use of the Aboriginal people in the Carngham district. In September 1865, the Secretary of the Central Board, $\mathrm{R}$ Brough Smyth, sent a letter to the President of the Board of Land and Works requesting the reservation of a block of land for the use of the Aboriginal people of the Carngham district. The preferred site was to the east of, and adjoining, Sections $x v$ and xiv Parish of Chepstowe. File notes record that the land formed part of a common on Baillies Creek. There were no departmental objections to this request being met. ${ }^{21}$

William Thomas, the Guardian of Aborigines, in his journal dated 17 March 1866, records an instance when he was visited by 14 of the Mount Emu people at his Merri Creek residence, en route to Coranderrk. ${ }^{22}$ In October 1866, Andrew Porteous reported that the Mount Emu tribe still preferred to roam about in small bands, from station to station and the various goldfields, returning at short intervals for a supply of the Board's stores. They continued to hunt possum and make rugs, for which they found a ready market, and the women also continued to make nets and baskets.

About 8 months ago, the chief of the tribe, with a number of others, visited Coranderrk, and stayed there for a few weeks. On his return, he described everything that he had seen, and he thought that the arrangements at Coranderrk were a great improvement on the former habits of the blackfellows. Some of the young men of the tribe, after seeing, and I suppose practising a little of the industry at Coranderrk, when they returned, were very anxious to get a job of fencing, so they could do it as well as the whitefellows. I have since seen some of them at work fencing, and doing the work very well. The aged of the tribe cannot be induced to remain at work more than an hour or two at a time. I still continue to supply the Board's stores in small quantities, what will do them for a few days only; although I have not known any of them to barter away their rations, yet if they had a larger quantity in their possession at one time I believe they would give it away for grog. The number of the tribe at present, as entered in my book, is $57 .{ }^{23}$

Guardian William Thomas has an interesting entry in his journal, dated 25 January 1867, in which he records a visit from Marmbarmin (aka Davy) of the Mount Emu tribe. Marmbarmin had been shearing and harvesting for Porteous at Carngham, and he informed Thomas that Porteous wished him (Marmbarmin) to return from Melbourne and get two women who were living with some white men in their tents at the

20. CBA 5th Report 1866.

21. Registered inward correspondence to the Surveyor General, Board of Lands and Works, unit 4, item L1865/10538, VPRS 2896, PROV.

22. Thomas Papers, vol 5, Mitchell Library.

23. CBA 6th Report 1869. 
Fiery Creek (Beaufort) gold diggings. Marmbarmin gave Thomas an 'awful account of drunkenness and disease' at the Fiery Creek and Ararat diggings. ${ }^{24}$

In September 1867, Porteous reported that the condition of the 47 Aboriginal people in his neighbourhood was unchanged. They continued to hunt seasonal game and fish in lakes and creeks where fish was available. They sold possum rugs and fish, and with the proceeds they bought themselves rations, and clothing such as hats, handkerchiefs and boots. The tribe seldom gathered together but travelled from station to station in bands of six or eight.

During the month of July last, it being wet and cold, a large number of the tribe camped with me, and the Board's stores were very acceptable, as the weather was such they could not hunt. Since then they have been travelling amongst the stations, only a few calling for rations. I have made no change to the manner of distributing stores. Each man receives a blanket, one serge shirt, one twill shirt, and a pair of trousers, and each woman a blanket and one dress; and to prevent them disposing of any article, I invariably brand each with oil paint. When they are camped with me I supply each twice a week with a small quantity of rations, and when they leave or make a call for rations, I give each about $10 \mathrm{lbs}$ of flour and 3lbs of sugar, with a proportion of tea, and $1 / 2 \mathrm{lb}$ of tobacco and $1 / 2 \mathrm{lb}$ of soap. ${ }^{25}$

Porteous informed the Board that he had received a letter from the Borough Council of Buninyong, requesting him to send as many Aboriginal people as possible to Buninyong, as the Borough Council was determined to stage a grand corroboree on the arrival of His Royal Highness Prince Alfred, the Duke of Edinburgh, in December 1867. Porteous stated that he had replied to the Borough pointing out the dangers and risks to Aboriginal people by allowing them to congregate near any large town. He cited as a proof of his concerns, an incident that occurred the previous summer when the Mount Emu and Hopkins tribes met at Ballarat, and gave a public corroboree. The Aboriginal people got so intoxicated for about a week that two of the Mount Emu tribe died shortly after returning to their district, and many others lingered in a sickly state for months. For this reason, Porteous informed the Board that he declined to comply with the request unless it had the sanction of the Central Board ${ }^{26}$ I have not been able to confirm if this corroboree took place.

Andrew Porteous reported in November 1869 that the Aboriginal people in his district were continuing their commercial activities, selling possum skin rugs, and fish, and shearing and harvesting.

The rations I supply, as usual, to all that are staying here. I give twice a week to each adult about $4 \mathrm{lbs}$ of flour, $1 \mathrm{lb}$ sugar, 2oz. tea, one fig of tobacco, a small piece of soap. When they are leaving or make a call I give them about 8 days' supply. They still hunt and make a number of rugs with the opossum skins, which they sell at from 10 to 20 shillings each, according to size. They also fish, when fish can be had, and sometimes offer fish for sale; they still indulge in intoxicating drink when they can get it. I believe that all the strong, healthy men of each tribe earn as much money during shearing and harvest season as would purchase sufficient

\footnotetext{
24. Thomas Papers, vol 5, Mitchell Library.

25. CBA 6th Report 1869.

26. CBA 6th Report 1869.
} 
clothing and keep them half the year. This is the very money that keeps them and the whole tribe in intoxication for weeks, and then they apply for food and clothing from the Board. ${ }^{27}$

Porteous reported in June 1871 that 30 people were continuing to receive aid from him: 17 men, aged from 30-65, and 13 women aged from 35-65. These people continued to follow their occupations of fishing, hunting and making possum rugs which they bartered for stores and alcohol. Porteous advocated the adoption of a pass system to regulate and restrict Aboriginal peoples' presence in townships. He believed they had no business to transact in towns other than to beg for grog and risk being arrested under the Vagrancy Act. Porteous suggested that as the Aboriginal people had no hunting field or fishing river within these towns that they should apply to the local guardian for a day pass if they have anything to sell within a town named on the pass. This system of spatial control had existed during the Port Phillip Aboriginal Protectorate when Chief Protector George Augustus Robinson introduced passes in June 1840: non-local Aboriginal people returning from Melbourne to their home country needed signed letters from Robinson, William Thomas the assistant protector responsible for the Melbourne District, or the Port Phillip District Superintendent CJ La Trobe, which were to be shown to squatters to ensure safe passage. Passes were also necessary if Aboriginal people wanted to enter townships. ${ }^{28}$ This system continued in the Protectorate until at least December 1844 when some Wathawurrung at Buntingdale Wesleyan Mission approached Thomas for passes allowing them to visit the Gulidjan at Lake Colac. The Wesleyan missionaries were preventing them from visiting the Gulidjan, and they explained to William Thomas that '[i]f no let them go to see Lake Colac kooling molocko all blackfellows leave Mr Tuckfield and no more sit down there' ${ }^{29}$

In May 1872, Porteous reported that Aboriginal spatial habits were continuing to be adhered to. In February 1873, he reported that he supplied stores to 14 males and 11 females. Two men had left the district: King John had gone to Framlingham, near Warrnambool and David Smith had gone to Coranderrk. Both men intended to make these stations their homes.

The tribe is mostly composed of old feeble men and women, who are by nature restless, and though they had every comfort, they would not stay long in one place but continue wandering from place to place. They are at no time short of both food and clothing. They still continue to make baskets and opossum rugs, and hunt and fish as usual; and even the old and feeble cannot be induced to stay where they can have plenty to eat and drink. They will be off on a hunting or fishing expedition. The whole tribe is on one of those expeditions just now, and has not been here for some weeks. 30

In July 1874, Smyth reported that the number of Aboriginal people receiving aid from the Local Guardian at Pretty Tower remained at 14 males and 11 females. ${ }^{31}$ Board reports reveal that no stores were distributed to Aboriginal people between 1 January

\footnotetext{
Board for the Protection of Aborigines (BPA) 7th Report 1871.

Clark 1998: 236.

Thomas Papers, vol 3, entry for 6 December 1844, Mitchell Library.

BPA 9th Report 1873.

31. RB Smyth, Memorandum to Sir GF Bowen, 18 August 1874, Governor's Office - special files, 1854-1900, VPRS 1095, PROV.
} 
1875 and 30 June 1877.32 Andrew Porteous died on 1 February 1877. His stepson, John Dempsey Porteous, in a letter sent to the Board, dated 3 March 1877, informed the secretary of the death of his stepfather.

Any stores or goods belonging to the Board over to any person whom you may authorise to receive them. I see by the books that your late guardian has advanced to the aborigines flour and tea in excess of what has been received from the Board accounts of which I believe you have been furnished with. ${ }^{33}$

Andrew Porteous had been distributing to his Aboriginal friends, flour and tea in excess of the supplies he had received from the Board.

Andrew Porteous enjoyed a significant relationship with the northern Wathawurrung from the early 1840s until his death in 1877. This is reflected in his willingness to employ Aboriginal labour and to allow them to reside on his Carngham property. The Aboriginal people of the district were given free access to his land, but despite his best efforts, he could never persuade them from continuing their adherence to their 'traditional' spatial organisation, that of semi-nomadism in small hunting and gathering 'bands'. When, from 1860, Porteous became an honorary correspondent to the Central Board, he distributed food and clothing rations on a regular basis. The Wathawurrung came and went as they pleased; they refused to be concentrated on one station despite being able to receive regular rations. They lived for short periods on his station when it suited them, and the able amongst them were employed when the station required extra labourers. Employment included such station tasks as sheep-washing, harvesting, cutting wood, stockriding, breaking in horses and other labouring jobs. They supplemented their wages by fishing and shooting wildfowl and other game. The Wathawurrung continued to make and sell possum skin rugs, for which they received between 20 to 30 shillings. Each rug took two weeks to make. Fish, as well, were sometimes sold to Europeans. The Wathawurrung women made baskets and nets and sold these to Europeans. It is highly likely that some of these baskets, nets and rugs are held in private and public collections throughout western Victoria.

During the time of Porteous' guardianship (1860-77), the Wathawurrung and Djabwurrung peoples lived in and travelled around the district as small groups, loosely referred to as the Mount Cole, Mount Emu and Wardyallock 'tribes'. Large gatherings were occasional; the usual praxis was for groups of about a dozen people to travel by themselves. The northern Wathawurrung bands travelled around their traditional lands in patterns that were probably consistent with pre-European times, but goldfields often proved to be disruptive locales for the Wathawurrung. The Wathawurrung lived for periods of time at the various diggings in their district and numerous men died after falling down mine holes when in a drunken state, others died by fire when in a state of intoxication. Some Wathawurrung women lived with European diggers. Commentators noted that during the 1850s, in particular, Aboriginal deaths from venereal disease were commonplace.

32. BPA 12th Report, 1876; 13th Report, 1877.

33. Local guardian, Carngham, 1877, Correspondence relating to various Aboriginal stations 1869-1957, series B 313, box 2, item 16, National Archives of Australia. 
There are many undercurrents in the relationship between the northern Wathawurrung and Andrew Porteous and the Board for the Protection of Aborigines. Porteous' paternalism, so typical in the latter part of the 19th century, is seen in his attempts to restrict the civil liberties of the Aboriginal peoples in the Ballarat district. He attempted to prevent them from entering townships, and advocated a system of passes to ensure that only Aboriginal people with 'legitimate' reasons would be permitted access to towns. Disrespectful of Aboriginal freedoms of movement and association, Porteous believed the Wathawurrung had no business to transact in townships, except begging for grog and making them liable to arrest under the Vagrant Act. There were neither hunting fields nor fishing rivers in these townships, and if the Aboriginal people had anything to sell, then Porteous advocated they should apply to a local guardian for a day pass that would allow them lawful access. He also sought to prevent their participation in a corroboree as part of a civil welcome to the Duke of Edinburgh. Yet, despite these efforts, the Wathawurrung showed a fierce determination to live as they pleased and visit the places of their choosing, such as pastoral stations and gold fields.

The northern Wathawurrung found a ready market for some of their traditional material culture. Possum-skin cloaks were sold for between 20 to 30 shillings and baskets and nets, and fish and wild fowl were also sold to Europeans. The monies received from these sales were used to buy rations, clothing and alcohol. The younger people, however, turned to European forms of employment such as stockriding, breaking in horses, sheep washing, shearing, harvesting, cutting wood, fencing and general labouring.

In early 1865 , seven children were taken to Coranderrk, and their parents left Carngham determined to visit the Aboriginal station and satisfy themselves that their children were well cared for. They remained at the station for four months. Upon their return to Carngham, and the information they passed on about the 'blackfellow's township', the rest of the northern Wathawurrung visited Coranderrk. When they returned, they petitioned Porteous to apply to the Board for a block of land at Chepstowe for their use. Their application was ultimately successful. Porteous welcomed this action, seeing it as little or nothing for the government to reserve two sections for a year or two whilst the tribe lasted. He believed the northern Wathawurrung would be extinct within a few years.

In the 1870s, the Board reported that it was neither practicable nor humane to compel the 'old natives against their inclination to abandon the localities where they were born, and to which they are strongly attached, but the children are being removed one by one and sent to the stations, where they are well cared for and taught in schools' ${ }^{34}$ After Porteous' death in 1877, no one was appointed to replace him as guardian, and the Board rationalised its operations by concentrating Aboriginal people onto government stations. It permitted the old and frail, many of whom resisted attempts to force them to move, to remain in their traditional lands where they were cared for by police officers and residents. The Chepstowe Reserve was closed in 1901 when the land was handed back to the Department of Lands, on the assumption that 'all the Aborigines of that district were all dead'. ${ }^{35}$ The Department of Lands was

34. BPA 11th Report 1875.

35. BPA 37th Report 1901. 
clearly mistaken: there were numerous Wathawurrung people still living on country on pastoral stations, on Aboriginal stations such as Coranderrk, and elsewhere in Victoria.

\section{References}

\section{Primary sources}

Blake, L nd, 'Colin Campbell, an unpublished biography', the Banfield Collection, Ararat Library.

Board for the Protection of Aborigines: Correspondence files, 1889-1893, VPRS 1694, Public Record Office of Victoria.

Coroner's Court inquest files, VPRS 24, Public Record Office of Victoria.

Correspondence relating to various Aboriginal stations 1869-1957, Series B 313, National Archives of Australia, Canberra.

Crown Solicitor's criminal trial briefs, 1841-1908, VPRS 30, Public Record Office of Victoria.

Governor's Office - special files, 1854-1900, VPRS 1095, Public Record Office of Victoria.

Colonial Secretary's Office - inward registered correspondence, Part 1, 1853-63, VPRS 1189, Public Record Office of Victoria.

Registered inward correspondence to the Surveyor General, Board of Land and Works, 1856-73, VPRS 2896, Public Record Office of Victoria.

Thomas, William, papers, set 214, items 1-24, Mitchell Library, Sydney.

Victoria Department of Crown Lands and Survey 1938, 'Carngham, Counties of Ripon and Grenville' [Cadastral map showing parish boundaries and land ownership], Department of Lands and Survey, Melbourne.

Victorian Legislative Council 1858-59, Report of the Select Committee of the Legislative Council on the Aborigines, Together with the Proceedings of the Committee, Minutes of Evidence, and Appendices, Victorian Government Printer, Melbourne.

\section{Secondary sources}

Anderson, H 1969, The Flowers of the Field: A History of Ripon Shire, Hill of Content, Melbourne.

Barwick, Diane 1972, 'Coranderrk and Cumeroogunga: pioneers and policy', in T Epstein and D Penny (eds), Opportunity and Response: Case Studies in Economic Development, Hurst, London: 10-68.

- 1979, 'An assessment of the cultural and historical significance to the present: Aboriginal community of the land reserved at Framlingham in 1861', unpublished report to the Land Conservation Council of Victoria.

— 1981, 'Equity for Aborigines? The Framlingham case', in P Troy (ed), A Just Society, George Allen \& Unwin, Sydney: 173-218.

- 1998, Rebellion at Coranderrk, Aboriginal History, Monograph 5, Canberra.

Billis, RV and AS Kenyon 1974, Pastoral Pioneers of Port Phillip, Stockland Press, Melbourne.

Board for the Protection of Aborigines 1871-1925, Reports of the Board for the Protection of the Aborigines in the Colony of Victoria, Victorian Government Printer, Melbourne. 
Central Board 1861-1869, Reports of the Central Board Appointed to Watch over the Interests of the Aborigines in the Colony of Victoria, Victorian Government Printer, Melbourne.

Clark, Ian D 1990, Aboriginal Languages and Clans: An Historical Atlas of Western and Central Victoria, 1800-1900, Monash University, Melbourne.

- 1998 'That's My Country Belonging to Me', Aboriginal Land Tenure and Dispossession in Nineteenth Century Western Victoria, Heritage Matters, Melbourne.

— 1999, 'The Victorian honorary correspondent supply depots scheme: Historical case studies', unpublished report to Aboriginal Affairs Victoria, Melbourne.

- 2000, The Journals of George Augustus Robinson, Chief Protector, Port Phillip Aboriginal Protectorate, vols 1-6, 1839-1852, Clarendon, Melbourne.

- 2006, 'Land succession and fission in nineteenth-century western Victoria: The case of Knenknenwurrung', Australian Journal of Anthropology 17(1): 1-14.

Cole, K 1984, Lake Condah Aboriginal Mission, self-published, Bendigo.

Gannan, K 1970, 'A patriarch of old: Peter Beveridge and the Aborigines, Swan Hill and Tyntynder, 1845-1877', BA (Hons) thesis, Melbourne University.

MacDonald, C 1963, 'Memories of Coranderrk', Victorian Historical Magazine 35: 102-105.

Marcard, P 1963, 'The Aborigines in Victoria 1858-84', BA (Hons) thesis, University of Melbourne.

— 1964, 'Early Victoria and the Aborigines', Melbourne Historical Journal, no 4: 23-29.

Massola, A 1963, 'A history of Lake Condah Aboriginal Reserve', Victorian Historical Magazine 34: 29-47.

— 1970, Aboriginal Mission Stations in Victoria: Yelta, Ebenezer, Ramahyuck, Lake Condah, Hawthorn Press, Melbourne.

- 1975, Coranderrk: A History of the Aboriginal Station, Lowden Publishing, Kilmore.

Penney, J 1997, 'Victorian honorary correspondent supply depots - final report', unpublished report to Aboriginal Affairs Victoria.

Reynolds, Henry 1981, The Other Side of the Frontier, James Cook University, Townsville.

Robertson, S 1992, The Bell Sounds Pleasantly: The Story of Ebenezer Mission, 1859-1902, Luther Rose Publications, Doncaster.

Shaw, E 1949, Early Days Among the Aborigines: The Story of Yelta and Coranderrk Missions, W \& J Barr, Melbourne.

Smyth, R Brough 1878, The Aborigines of Victoria and Other Parts of Australia and Tasmania, 2 vols, John Ferres, Government Printer, Melbourne.

Spreadborough, R and H Anderson 1983, Victorian Squatters, Red Rooster Press, Ascot Vale.

Swain, T 1993, A Place for Strangers: Towards a History of Australian Aboriginal Being, Cambridge, Melbourne.

Werner, A 1964, Early Mission Work at Antwerp, self-published, Dimboola. 